\title{
Production of mycotoxins by Fusarium isolates from scabby wheat harvested in Hokkaido, Japan
}

\author{
T. TANAKA ${ }^{* 1}$, A. HaSegaWi ${ }^{* 1}$, S. Yamamoto*1, M. ToYazaki*1, \\ Y. MATSUDA*1, Y. SUGIURA*2, and Y. UENO ${ }^{* 2}$ \\ 田中 敏嗣 ${ }^{* 1}$, 長谷川明彦*1, 山本 進*1, 戸矢崎紀紘 ${ }^{* 1}$, 松田 良夫*1, \\ 杉浦 義紹 ${ }^{* 2}$, 上野 芳夫 ${ }^{* 2}$ : 北海道産赤かび罹病小麦より分離した \\ Fusarium 属菌のマイコトキシン生産性
}

\begin{abstract}
Summary
A total of 35 strains of Fusarium species were isolated from the scabby wheat grains harvested in Hokkaido which have been found to be contaminated with deoxynivalenol (DON), nivalenol (NIV) and zeralenone (ZEN), and were examined on their producibility of mycotoxins such as trichothecenes and ZEN.

DON and/or ZEN-producers of Fusarium graminearum and NIV and/or ZEN-producers of $F$. poae were detected. This is the first finding that $F$. poae produces NIV in rice culture.
\end{abstract}

In the preceding paper ${ }^{1}$, we have revealed the co-contamination of Fusarium mycotoxins, viz. nivalenol (NIV), deoxynivalenol (DON) and zearalenone (ZEN), in scabby wheat grains harvested in 1984 at Tokachi district of Hokkaido, Japan. In this communication, we aimed to clarify thier mycological occurrence.

\section{Materials and Methods}

Three scabby wheat samples (sample Nos. H4, $\mathrm{H} 8$ and $\mathrm{H10}$ ), which have been found to be contaminated with $2090-4900 \mathrm{ng} / \mathrm{g}$ of DON, $125-435$ $\mathrm{ng} / \mathrm{g}$ of NIV and $77-95 \mathrm{ng} / \mathrm{g}$ of $\mathrm{ZEN}$, were used for mycological survey. After surface-sterilization

*1 Division of Food Chemistry, Public Health Research Institute of Kobe City (4-6, Minatojimanaka-machi, Chuo-ku, Kobe 650) 神戸市環境保健研究所（矛650 神戸市中央区港 島中町4-6)

*2 Department of Toxicology and Microbial Chemistry, Faculty of Pharmaceutical Sciences, Science University of Tokyo (12, Ichigaya, Shinjuku-ku, Tokyo 162) 東京理科大学 薬学部 毒性学 - 微生物化学教室 （テ162 東京都新宿区市ヶ谷船河原町12） with $1 \%$ sodium hypochlorite solution for $1 \mathrm{~min}$, the grains were plated on potato-dextrose agar (PDA) or Czapek-Dox agar supplemented with $0.01 \%$ chloramphenicol in Petri dishes. The plates were incubated at $25^{\circ} \mathrm{C}$ for 7 days, and the developing fungi were isolated. The colonies of Fusarium species were singly transferred to PDA slants. The identifications of Fusarium isolates were carried out by the method of Booth ${ }^{2)}$, and the producibility of Fusarium mycotoxins was performed according to the previous repor $\mathrm{t}^{3)}$, as follows.

Each of Fusarium isolates was cultured at $25^{\circ} \mathrm{C}$ for 21 days in $50 \mathrm{~g}$ of polished rice grains supplemented with $16 \mathrm{ml}$ of water. The artificially molded rice was dried in a hot-air drying oven at $45^{\circ} \mathrm{C}$ for $40 \mathrm{hr}$, and finely powdered in a blender. Fusarium mycotoxins in the molded rice were extracted and purified by the previous method ${ }^{4)}$ summarized briefly as follows. The samples $(5 \mathrm{~g})$ were extracted with acetonitrile-water $(3: 1, v / v)$, and the extracts were defatted with n-hexane. After an addition of ethanol to the aqueous 
acetonitrile layer, the solvents were evaporated on a rotary evaporator. The residue was purified by a chromatographic procedure using a Florisil column. Fusarium mycotoxins such as DON, NIV, ZEN, T-2 toxin (T-2), diacetoxyscirpenol (DAS) and neosolaniol (NS), in column eluates were derivatized to trimethylsilyl ethers, and their amounts were estimated by gas chromatography-mass spec- trometry (Hitachi Model M-80A, Hitachi Ltd., Tokyo) with selected ion monitoring mode. The detection limits were $50 \mathrm{ng} / \mathrm{g}$ for DON, NIV and ZEN, and $100 \mathrm{ng} / \mathrm{g}$ for T-2, DAS and NS.

\section{Results and Discussion}

As shown in Table 1, a total of 35 strains of Fusarium species were isolated from the scabby

Table 1. Production of mycotoxins by Fusarium isolates from wheat harvested in Hokkaido

\begin{tabular}{|c|c|c|c|c|}
\hline \multirow{2}{*}{ Species } & \multirow{2}{*}{ Strain No. } & \multicolumn{3}{|c|}{ Production of mycotoxins*1 $(\mathrm{ng} / \mathrm{g})$} \\
\hline & & DON & NIV & ZEN \\
\hline$F$. equiseti & H8F14 & $\mathrm{ND}^{* 2}$ & $\mathrm{ND}$ & ND \\
\hline F. graminearum & $\mathrm{H} 4 \mathrm{G} 1$ & 290 & ND & 270 \\
\hline " & H4G2 & 290 & ND & 5300 \\
\hline$\prime \prime$ & $\mathrm{H} 4 \mathrm{G} 20$ & 140 & ND & 3200 \\
\hline$\prime \prime$ & H8G3 & 230 & ND & 5300 \\
\hline$\prime \prime$ & H8G4 & 2000 & ND & 8000 \\
\hline$\prime \prime$ & H8G5 & 15000 & ND & 1800 \\
\hline$\prime \prime$ & H8G6 & 50 & ND & 1200 \\
\hline$\prime \prime$ & H8G7 & ND & ND & 50 \\
\hline$\prime \prime$ & H8G8 & 430 & ND & 5800 \\
\hline$\prime \prime$ & H8G9 & 400 & ND & 14500 \\
\hline$\prime \prime$ & H8G10 & ND & ND & 610 \\
\hline$\prime \prime$ & H8G11 & 1300 & ND & 63900 \\
\hline$\prime \prime$ & H8G12 & 400 & ND & 26100 \\
\hline$\prime \prime$ & H8G13 & 200 & ND & 1700 \\
\hline$\prime \prime$ & H8G14 & 370 & ND & 16000 \\
\hline$\prime \prime$ & H8G15 & 140 & ND & 980 \\
\hline$\prime \prime$ & H8G16 & 4900 & ND & 6200 \\
\hline$\prime \prime$ & H8G17 & 1300 & ND & 28000 \\
\hline$\prime \prime$ & H10G18 & 60 & ND & 1300 \\
\hline "I & H10G19 & 900 & ND & 81000 \\
\hline F. poae & H4F9 & ND & 380 & 310 \\
\hline "I & $\mathrm{H} 4 \mathrm{~F} 10$ & ND & 130 & ND \\
\hline$\prime \prime$ & $\mathrm{H} 4 \mathrm{~F} 11$ & ND & 250 & ND \\
\hline$\prime \prime$ & $\mathrm{H} 4 \mathrm{~F} 12$ & ND & 80 & ND \\
\hline$\prime \prime$ & $\mathrm{H} 4 \mathrm{~F} 13$ & ND & 130 & ND \\
\hline$\prime \prime$ & H8F18 & ND & 340 & ND \\
\hline$\prime \prime$ & H8F20 & ND & ND & ND \\
\hline "I & H8F21 & ND & 80 & ND \\
\hline F. tricinctum & H8F19 & ND & ND & ND \\
\hline Fusarium sp. & H8F15 & ND & 460 & ND \\
\hline "I & $\mathrm{H} 8 \mathrm{~F} 16$ & 110 & ND & ND \\
\hline$\prime \prime$ & H8F 17 & 230 & ND & ND \\
\hline$\prime \prime$ & H8F22 & 110 & ND & ND \\
\hline$\prime \prime$ & H8F23 & ND & ND & ND \\
\hline
\end{tabular}

*1 DON: deoxynivalenol, NIV: nivalenol, ZEN: zearalenone.

*2 ND: not detected (the limits of detection are $50 \mathrm{ng} / \mathrm{g}$ for DON, NIV and ZEN). 
wheat and they were identified as $F$. graminearum (20 strains), $F$. equiseti (1 strain), $F$. poae ( 8 strains), F. tricinctum (1 strain) and Fusarium sp. (5 strains).

Their producibility of Fusarium mycotoxins in rice culture was as follows. Among 20 strains of $F$. graminearum, 18 produced DON in range of $50-15,000 \mathrm{ng} / \mathrm{g}$ and 20 produced $Z E N$ in range of $50-81,000 \mathrm{ng} / \mathrm{g}$. The average productions of DON and ZEN by the toxin-producing strains were estimated to be 1,578 and $1,356 \mathrm{ng} / \mathrm{g}$, respectively. The present data supported the finding of Ichinoe et al..$^{5)}$ that $F$. graminearum in the wheat collected from Hokkaido produced DON.

Interestingly, in addition to the high producibility of $F$. graminearum for DON and ZEN, 7 out of 8 strains of $F$. poae procuced $80-380 \mathrm{ng} / \mathrm{g}$ of NIV, among which one isolate also produced ZEN. This is the first finding that $F$. poae produces NIV in rice culture. The details of morphological features of the $F$. poae strains will be reported elsewhere.

No production of DAS, T-2 and NS was encountered on the strains in the present survey.

To summing up the above results, the scabby wheat grains from Hokkaido have been infected with DON and ZEN-producers of $F$. graminearum and NIV and/or ZEN-producers of $F$. poae. Thus the DON and ZEN contaminations occurred in the scabby wheat mainly resulted in the invasion of $F$. graminearum, while the presence of NIV seems to be caused by $F$. poae.

\section{Acknowledgements}

This experiment was partly aided by the research grants from the Japan Private School Promotion Foundation (Tokyo) and the Foundation for Promotion of Food Science and Technology (Ichikawa).

\section{References}

1) Tanaka, T., Hasegawa, A., Matsuki, Y., Matsui, Y., Lee, U.-S., Ueno, Y.: J. Food Hyg. Soc. Japan, 26, 519 (1985).

2) Booth, C.: "The Genus Fusarium" p. 7 (1971), Commonwealth Mycological Institute, Kew, Surrey, England.

3) Tanaka, T., Hasegawa, A., Yamamoto, S., Matsuki, Y., Ishii, K., Ueno, Y.: Proc. Jpn. Assoc. Mycotoxicol., 24, 60 (1986).

4) Tanaka, T., Hasegawa, A., Matsuki, Y., Ishii, K., Ueno, Y.: Food Additives and Contaminants, 2, 125 (1985).

5) Ichinoe, M., Hagiwara, H., Kurata, H.: "Toxigenic Fungi-Their Toxins and Health Hazard" (Kurata, H., Ueno, Y., eds.), p. 190 (1984), Elsevier, Amsterdam. 